\title{
Innovative entrepreneurship in emerging and developing economies: the effects of entrepreneurial competencies and institutional voids
}

\author{
Amirmahmood Amini Sedeh ${ }^{1} \cdot$ Amir Pezeshkan $^{2} \cdot$ Rosa Caiazza $^{3}$ D
}

Accepted: 22 July 2021 / Published online: 31 July 2021

(c) The Author(s) 2021

\begin{abstract}
Innovative entrepreneurship is one of the key drivers of economic development particularly for less developed economies where the economic growth is at the forefront of policymakers' agenda. Yet, the research on how various factors at different levels interact and bring about innovative entrepreneurship in emerging and developing countries remains relatively scarce. We address this issue by developing a multilevel framework that explains how entrepreneurial competencies attenuate the negative impact of innovation barriers. Our analysis on a sample of individuals from 24 economies, 17 developing and 7 emerging countries, reveals that entrepreneurial competencies become more instrumental for innovative entrepreneurship when general, supply-side, and demand-side innovation barriers are higher. The findings offer unique insights to policymakers particularly in developing countries interested in promoting innovative entrepreneurship and to entrepreneurs and investors seeking to establish and support innovative ventures.
\end{abstract}

Keywords Innovative entrepreneurship $\cdot$ Innovation barriers $\cdot$ Emerging economies $\cdot$ AMO

JEL Classification $\mathrm{M} 13 \cdot \mathrm{O} 31 \cdot \mathrm{O} 32$

Rosa Caiazza

rosa.caiazza@uniparthenope.it

Amirmahmood Amini Sedeh

aaminisedeh@ship.edu

Amir Pezeshkan

apezeshkan@ubalt.edu

1 Department of Management, Marketing, and Entrepreneurship, John L. Grove College of Business,

Shippensburg University, Shippensburg, PA 17257, USA

2 Department of Management and International Business, Merrick School of Business, University of Baltimore, Baltimore, MD 21201, USA

3 Parthenope University of Naples, Naples, Italy 


\section{Introduction}

Comparative entrepreneurship research establishes a strong link between entrepreneurship and economic growth and development (Acs et al., 2016; Wennekers \& Thurik, 1999). Yet, not all entrepreneurship is created equal, and high-growth potential innovative ventures have been identified to contribute to economic growth the most (Autio, 2005; Shane, 2009). Innovative entrepreneurship (IE) includes entrepreneurial ventures that provide new products or service or develop and use new methods to produce products or offer services (Baumol et al., 2007, p. 3). They create jobs, promote shared prosperity, reduce inequality, and foster competitiveness all of which lead to sustained economic growth, one of the major objectives of policy makers particularly in developing and emerging markets (Caiazza, 2016). Innovative ventures require a supportive ecosystem to emerge, survive, and grow. Prior studies have documented the significance of national institutions as one of the essential elements of such ecosystem (Fagerberg \& Srholec, 2008). However, many countries that urgently need to promote IE and benefit from its significant economic impact often do not possess a full array of institutions that support innovative ventures and consequently struggle with barriers that hinder the diffusion and transformation of innovation (e.g., Caiazza, 2016; Estrin et al., 2006).

While various institutional voids and innovation barriers have been identified to impede IE in emerging and developing economies (EDEs) (Bu \& Cuervo-Cazurra, 2020; Hitt, 2016), there is evidence that entrepreneurs' individual attributes can play an important role in coping with these barriers in the process of creating innovative ventures. For instance, entrepreneurs with excessive financial resources usually engage in entrepreneurial activities irrespective of regulatory or cognitive support in emerging countries (Lim et al., 2016). Similarly, according to Bischoff et al., (2020), entrepreneurial training attenuates the negative effects of capital constraints on new business creation. Although prior entrepreneurship research has proven that entrepreneurial activities are influenced by the characteristics of both actors (i.e., entrepreneurs) and non-actors (i.e., environment) (Davidsson, 2015; Davidsson \& Wiklund, 2001), there is a lack of systematic research that examines whether and how individual competencies might compensate for various environmental barriers of IE (Block et al., 2017).

To address this gap, we extend current research on mechanisms through which entrepreneurial competencies exert their effect by adopting a perspective that examines their interplay with macro country-level barriers in bringing about IE in EDEs. To do so, we draw on ability, motivation, and opportunity (AMO) framework which identifies major individuallevel competencies linked to innovative practices (Prieto Pastor et al., 2010; Shipton et al., 2017) at the micro-level, and innovation diffusion barriers (i.e., general, supply-side, and demand-side barriers) at the macro-level (Bruton et al., 2008). Our multilevel framework posits that innovation constraints in EDEs elevate the significance of entrepreneurial competencies that enable entrepreneurs to bypass the barriers to engage in IE.

Our study makes several contributions to theory and practice. First, while prior studies on IE have advanced our understanding about its institutional requirements, they are mostly unidimensional. Our study is a response to call for multilevel research in this domain (Lim et al., 2016). We argue that in EDEs, entrepreneurial competencies play a critical role in facilitating IE by reducing the negative influence of (often substantial) innovation barriers. For instance, entrepreneurial motivation in environments marked by cultural voids (general barriers) facilitates innovative ventures, since the need for independence resulted from strong pull motives compensates for the lack of legitimacy of risky innovative activities in 
such societies (Shane et al., 2003). This new perspective goes beyond the typical effects of entrepreneurial competencies which has been discussed in prior research (González-López et al., 2020; Mitchelmore \& Rowley, 2010). We suggest that entrepreneurial competencies have the potential to help overcome the burden of innovation barriers in EDEs by dampening their negative impact.

Second, we connect the literature on individual competencies with institutional context (e.g., Bowen \& De Clercq, 2008; De Clercq et al., 2013) for the specific case of innovative entrepreneurial behavior (e.g., Baumol, 1996; Block et al., 2017). While the nature of contextual forces and consequences of weak institutions have sparked new discussions (Khoury et al., 2014; Kumar et al., 2013), there is a dearth of research connecting institutional theory with contemporary issues of entrepreneurship in these contexts (Web et al., 2019). Also, previous studies on the effects of evolving environmental factors on entrepreneurship have resulted in equivocal findings. For instance, supporters of "institutional entrepreneurs" concept argue that institutional challenges yield more opportunities for alert entrepreneurs since they can bypass the burdensome institutions or create new substitutes for missing ones (e.g., Estrin et al., 2006; Tracey \& Philips, 2011). On the other hand, the proponents of "institutional escapism" view claim that barriers and voids in institutions limit the range of available opportunities (De Clircq et al., 2010; Manolova et al., 2008; Witt \& Lewin, 2007). We believe that narrowing down the type of entrepreneurial activities from general new business development and exploring the more innovative entrepreneurial endeavors can help resolve these conflicting findings. In particular, our study shows while institutions have an important role in emergence and growth of IE, in countries demonstrating institutional voids and barriers, individual characteristics of entrepreneurs can help circumvent the voids. Hence, our study lends support to "institutional entrepreneurs" view and advances this notion by adding individual level contingencies.

Finally, we adopt the notion of "Schumpeterian entrepreneurs" distinguished by the ability and willingness to disrupt the market equilibrium by developing new products and technologies (Schumpeter, 1983). This notion has received more attention recently as the type of entrepreneurship has the outmost economic impact (Shane, 2009). By shedding light on possible ways to overcome innovation barriers in EDEs, we move the literature one step further in promoting high-impact entrepreneurial activities critically needed in these countries. While directly addressing and overcoming innovation barriers often involves rather long and resource intensive transition periods, our findings suggest that fostering, promoting, and developing specific individual competencies may be viable solutions enabling IE until the institutional barriers are addressed.

\section{Theoretical development}

\subsection{Innovative entrepreneurship}

An innovative entrepreneurial venture "provides a new product or service or ... develops and uses new methods to produce or deliver existing goods and services at lower cost" (Baumol et al., 2007). Thus, innovativeness encompasses any economic change that expresses a creative aspect (Hayek, 1994), and innovative ventures have been shown to create a higher economic impact (Wennekers et al., 2005).

Many factors at both micro- and macro-levels influence the cross-country differences in entrepreneurial activities in general and innovative new venture creation in particular 
(Shane \& Venkataraman, 2000). Micro (i.e., the actor)-level factors including mental and behavioral prerequisites for opportunity identification, initiation, persistence, and success can partially explain cross-country variation in IE. Additionally, macro (i.e., country)-level factors set the boundary conditions for innovative venture development by influencing the context in which individuals pursue opportunities. Thus, the interaction between the two groups of factors ultimately determines the level of IE in any particular country. This issue is particularly relevant in emerging and developing countries, where there are substantial innovation barriers such as ineffective property rights (Khoury et al., 2014), inefficient capital market (Khoury et al., 2015), poor understanding of innovation timing and required improvements (Caiazza, 2016), and users' uncertainty about the usage, risks, and application of new products (Edler, 2011).

\subsection{Individual-level competencies and innovative entrepreneurship}

According to supply-side perspective of entrepreneurship, entrepreneurs not only possess certain abilities but also demonstrate specific behaviors that distinguish them from nonentrepreneurs and drive entrepreneurial intentions and actions (Aldrich \& Martinez, 2001). Consistent with this perspective, the ability-motivation-opportunity (AMO) framework suggests that individuals' ability, motivation, and opportunity seeking attitude are the significant drivers of success in any task they undertake (Blumberg \& Pringle, 1982; Boxall \& Purcell, 2008).

Previous literature has linked AMO components to innovative behavior (Shipton et al., 2017). For instance, Prieto et al. (2010) evaluate human resource practices that affect and enhance ability, motivation, and opportunity and find that such practices have a positive influence on new knowledge creation. We employ the AMO framework and define the main individual-level entrepreneurial competencies influencing IE as perceived entrepreneurial ability (PEA), entrepreneurial motivation (EM), and perceived entrepreneurial opportunity (PEO).

PEA refers to the individual's beliefs in their ability to recognize or initiate innovative opportunities resulted from social and economic changes (Chen et al., 1998; Drnovšek et al., 2010). Given the fact that innovativeness is often fraught with ambiguity, IE is more likely to occur when entrepreneurs have higher levels of confidence in their skills and expertise (Koellinger et al., 2007). Additionally, differences in entrepreneurs' motivations will impact the type of opportunities they pursue, type of resources they assemble, and the process they undertake. According to the AMO framework, EM refers to the willingness to exploit innovative opportunities. Prior research defines two types of entrepreneurial motives: "pull" and "push" motives (Acs, 2006). While pull motives arise from identifying a specific opportunity, individuals are pushed towards self-employment because other options are either absent or unsatisfactory (e.g., being laid off during recession). Entrepreneurs gravitated to a specific opportunity have a more aggressive preference toward venture growth and taking risk (Baum \& Locke, 2004). Since innovativeness is associated with high growth orientation and a risk-taking attitude, pull motivation can facilitates IE (Morris et al., 2006).

Another driver of individuals' engagement in IE is their evaluation and subjective perception of opportunity (McMullen \& Shepherd, 2006). According to Kirzner (1973), PEO is the result of the entrepreneur's evaluation of a situation conductive for new economic activity. Many of the prior studies have in fact assumed innovation as an inherent part of opportunity. For instance, Gaglio (2004: 534) bolsters the innovative nature of 
entrepreneurial opportunities by contrasting innovative and imitative ideas and suggests that entrepreneurial opportunities are "the chance to introduce innovative (rather than imitative) goods, services, or processes to an industry or economic marketplace."

In sum, prior studies indicate that the three elements of the AMO framework (ability, motivation, and opportunity) are positively associated with innovative venture creation.

\subsection{The joint effect of entrepreneurial competencies and innovation barriers on IE}

The demand-side perspective of entrepreneurship maintains that in addition to individual attributes, broad contextual factors can impact the rate and type of entrepreneurship (i.e., IE). Voids in these contextual factors can indeed function as barriers to IE. Caiazza (2016) classifies innovation diffusion barriers into three categories: general, supply-side, and demand-side barriers.

The general barriers of innovation refer to legal, economic, and cultural obstacles that may hinder the innovation process and thus innovative venturing (Caiazza, 2016). These general barriers represent weaknesses and voids in national institutions, which are more prevalent in EDEs (Marquis \& Raynard, 2015; Webb et al., 2019).

In the context of IE, general institutional barriers speak to uncertainty in intellectual property rights and ineffective political system (i.e., regulatory voids), ineffective fiscal structure and financial mechanics (i.e., economic voids), and negative attitudes towards entrepreneurship and risk taking (i.e., cultural voids). The general regulatory voids consist of barriers related to laws and policies that may constrain certain types of activities (Kostova \& Roth, 2002). Ineffectiveness (or lack) of regulations creates uncertainty about contracts and mechanisms that offer safeguards for intellectual property rights which are central for IE (Olavarrieta \& Villena, 2014). Regulatory voids also constrain knowledge transfer and collaborative R\&D efforts, the cornerstones of IE (Autio, 2005).

General economic voids reflect weaknesses in financial systems. Entrepreneurs are vulnerable to economic barriers, particularly during the early stages of the venture creation (Aldrich \& Fiol, 1994). Voids in financial systems limit access to required capital through providers such as banks and credit unions or venture capitalists (VCs). Financial constraints are more pronounced for IE due to the uncertainty of return, limited collateral value, and information asymmetries that are inherent in innovative activities (Carpenter \& Petersen, 2002).

General cultural barriers of innovation are tied to poor business climate as well as individuals' and firms' negative attitude toward novel activities. In advanced economies, innovative entrepreneurs are known to be the driving force of economic growth (Livesay, 1982). However, in some countries, social norms, values, and beliefs are less likely to favor innovative entrepreneurial activities (Verheul et al., 2002). For instance, in many developing and emerging economies, innovative entrepreneurial activities are marked by profiteering. Similarly, the risk-taking attitude involved in innovation has a negative connotation (Bruton et al., 2008; Manolova et al., 2008) and thus, cultural barriers make it harder for innovative entrepreneurs to establish their identity and legitimacy (Lounsbury \& Glynn, 2001).

We argue that in the presence of general barriers for innovation (i.e., regulatory, cultural, and economic), the role of entrepreneurial motivation in bringing about IE is more pronounced. For instance, emerging countries with regulatory obstacles are characterized by overly complex bureaucracies and burdensome administrative procedures related to starting or closing a business (Capelleras et al., 2008) which may hinder the willingness 
of entrepreneurs to invest in productive assets (Khoury \& Cuervo-Cazurra, 2014). General barriers to innovation also include lack of effective intellectual property right (IPR) protection. Intellectual properties are the essence of IE (Alexander, 2012) and absence or inefficacy of laws protecting them makes it burdensome for innovative ventures to survive. Given that entrepreneurial pull motive involves acting in the face of uncertainties and accepting unknowns with respect to career challenges, it diminishes the negative impact of insufficient legal protection by tapping into their risk-taking attitude and growth-oriented ambitions (Shane et al., 2003). Conversely, in countries with lower regulatory innovation barriers and a more conducive environment to IE, (e.g., reliable IPR systems, predictable and consistent rule of law and policies, and less turbulent environments) the entrepreneurs' motivation plays a less significant role in predicting innovative venture creation.

Similarly, we suggest that when social values, believes, and norms are unfavorable toward innovative activities, the need for achievement and independence derived from entrepreneurial motivation should function as a more significant aid to overcome the cultural innovation barriers (Stephan \& Uhlaner, 2010). That is because individuals with pull motives tend to question the common assertations of the society and use their own judgments (Shane et al., 2003). Thus, lack of legitimacy of innovative activities in the eyes of the public may be compensated by a strong pull motive. In contrast, when the overall attitude of a country toward innovative activities is more favorable, the value of innovative new businesses is wildly accepted. Therefore, extensive entrepreneurial motivation may be less instrumental in initiating innovative ventures.

Further, motivated entrepreneurs are better equipped to cope with economic barriers of innovation because they have a clear vision of the future and an ambition to monetize a new idea (Baum et al., 2001). Therefore, they set clear quantitative goals for each outcome and often devote significantly more time and resources to their innovative venture, irrespective of the absence of a broader support from economic institutions (Lim et al., 2016). In contrast, countries with lower economic barriers have financial mechanisms in effect aimed at facilitating the entrepreneurs' access to required resources and providing incentives such as lower taxes, favorable depreciation schedules, and corporate insurances. Thus, the role of self-motivating mechanisms to cope with the risky decision of starting a new innovative business is less pronounced.

Together, we expect:

Hypotheses 1a, 1b, \& 1c In EDEs, the relationship between EM and IE is moderated by the country's general (a) legal barriers (b) economic barriers, and (c) cultural barriers, such that the relationship is stronger when the barriers are higher.

The second set of innovation obstacles includes supply-side barriers. With respect to IE, supply side barriers refer to market resistance to innovative products and obstacles to innovation adaptation for new ventures (Caiazza, 2016). When an innovation is realized, issues such as poor understanding of the technology, product and service required alternations, entry costs, and timing of commercialization may endanger the success of the innovative entrepreneurial activity (Caiazza, 2016). Therefore, given that innovation is a knowledge intensive activity, entrepreneurs encounter supply-side obstacles when they lack the skills and technical assistance to adapt the innovation to the market's needs and improve their technology (Dakhli \& De Clercq, 2004). Although, knowledge about how to manage and grow a business in countries with salient institutions (i.e., developed countries) may be widely available, in countries suffering from supply-side innovation 
barriers, entrepreneurs may lack a detailed understanding of business processes, innovative opportunities identification, and necessary resource bundles (Manolova et al., 2008).

We posit that supply-side deficiencies give rise to the importance of PEA in generating IE. The resulted mental preparedness from higher levels of PEA helps entrepreneurs to grasp, analyze, and synthesize relevant information and thus, enhances their openness, flexibility, and independent thinking as the vital prerequisites to engage in self-initiated professional actions (Schwartz, 2006). Similarly, Individuals with higher levels of PEA are more resilient in overcoming the barriers to identifying possible improvements, lowering the entry costs, providing complimentary products, and adapting the innovation to different contexts (Rosenberg, 1972) and thus, engage more in IE. PEA may also help fill the knowledge gaps and overcome supply-side barriers by offering a better understanding and skill set pertaining to new product development and other forms of innovation (Pezeshkan et al., 2016). Furthermore, when supply-side barriers are high, individuals with higher levels of PEA are in a better position to predict and control the market for their innovative products and have a higher general confidence that running an innovative business is a feasible career, regardless of the obstacles (Spencer \& Gomez, 2004).

Conversely, when supply-side barriers are lower, reliable information about the availability of resources and exploiting innovative opportunities are widely available to public. Particularly, entrepreneurs can easily and successfully seek assistance in complicated tasks such as developing business plans, feasibility analyses, and product modification (De Clercq et al., 2010). Thus, the strength and availability of such resources can relatively weaken the role of entrepreneurs' individual skills, knowledge, and expertise in pursuing IE.

Hypotheses 2 In EDEs, the relationship between PEA and IE is moderated by the supply-side barriers, such that the relationship is stronger when the barriers are higher.

The third type of constrains, demand-side barriers, include the obstacles to adopting and becoming aware of an innovation (Caiazza, 2016). They are usually the result of unavailability of information about the advantages and disadvantages of the innovation and lack of interaction between the innovative new ventures and users. Markets that demonstrate such voids do not offer a quality infrastructure such as telecommunication systems to connect businesses to their customers, mechanisms to receive feedback from customers, and redress means for products that do not deliver what is promised (Cavusgil et al., 2002; Khanna \& Palepu, 1999).

In countries with higher demand-side barriers-where markets for innovative products are insufficiently developed and users encounter difficulties finding the right products/services that fulfil their needs-PEO may enable innovative entrepreneurs to overcome demand-side obstacles. Entrepreneurs with higher PEO initiate economic progress by identifying novel ways of putting productive resources to use. Additionally, given that customer needs lie at the heart of entrepreneurial opportunities (Prandelli et al., 2016), tangible innovation opportunities are usually perceived because of face-to-face idea exchanges and informal meetings with customers (Venkataraman, 2004). One reason why individuals with higher levels of PEO are better capable of informing potential customers and public about their innovative products and services is their extensive engagements in networks that facilitates interaction and information exchange (Hoang \& 
Antoncic, 2003). Thus, when demand-side barriers are high, entrepreneurs with higher levels of PEO are more capable in alleviating the negative impacts of those barriers and reaching out to a broader set of customers and hence more likely to engage in IE.

However, in advanced economies with lower demand-side barriers, there is a heavy pull from sophisticated buyers leading entrepreneurs to create more innovative solutions to satisfy their needs (Porter, 1990). In such settings where there is an effective infrastructure in place, customers are often actively seeking information about the application of new technologies, willing to pay the learning and adaptation costs, and more connected with informal hubs of promoting the application and benefits of new products (Edler, 2011). Thus, individual entrepreneurs' PEO may be less essential to launch innovative ventures.

Hypotheses 3 In EDES, the relationship between PEO and IE is moderated by the demand-side barriers, such that the relationship is stronger when the barriers are higher.

\section{Methods}

\subsection{Data and sample}

We used several reliable sources to measure the construct employed in our analysis. First, to determine the individual-level drivers of IE, we used data from Global Entrepreneurship Monitor's (GEM) Adult Population 2016 Survey (APS). GEM data-base has been widely used by prior studies on international entrepreneurship (e.g., Bowen \& De Clercq, 2008; Estrin et al., 2016; Stenholm et al., 2013; Stephan et al., 2015). For each participating country in the GEM APS, a survey is conducted on a representative sample of adults from 18 to 64 years old. To explore our study's research question, we limited countries to emerging economies provided by Hoskisson et al. (2013), included developing and transition countries and excluded developed countries (e.g., US, UK, Sweden, Germany, and Japan).

Second, we used World Economic Forum (WEF) and GEM national experts survey (NES) to measure country level innovation barriers (i.e., general, supply, and demand). NES surveys each country's experts who represent a range of background and knowledge on the overall entrepreneurial climate in that country (Reynolds et al., 2005). Our final sample consists of over 4,000 entrepreneurs in 24 countries for which data was available for all key variables at individual- and national-level. Table 1 illustrates the list of countries used in our study, their IE rates, and the extent of innovation barriers in each country.

\subsection{Measures}

\subsubsection{Innovative entrepreneurship}

The dependent variable of this study is innovative entrepreneurship. Some of the common measures of innovation are not appropriate for our context. For instance, R\&D intensity underestimates the significance of innovative activities occurring in small entrepreneurial firms (Kleinknecht, 1987). Similarly, patent data is more proper for larger and more mature firms (Samuelsson \& Davidsson, 2009). As a result, in line with innovation literature, we combine product innovation and process innovation to constitute a composite measure of innovativeness (Rosenbusch et al., 2011). For product innovation, GEM asks respondent "How many (potential) customers consider your product new/unfamiliar?" (1=all, 
Table 1 Countries and innovation barriers

\begin{tabular}{|c|c|c|c|c|c|c|c|}
\hline \multirow[t]{2}{*}{ Country } & \multirow[t]{2}{*}{ Economy } & \multirow[t]{2}{*}{$\mathrm{IE}^{\mathrm{a}}$} & \multicolumn{5}{|c|}{ Innovation barriers } \\
\hline & & & Economic & Legal & Cultural & Supply & Demand \\
\hline Argentina & Developing & 24.9 & 4.1 & 3.6 & 1.9 & 3.1 & 3.8 \\
\hline Brazil & Developing & 12.4 & 2.6 & 4.3 & 3.1 & 3.9 & 3.4 \\
\hline Bulgaria & Emerging & 17.5 & 2.6 & 3.1 & 3.4 & 3.8 & 2.9 \\
\hline Chile & Developing & 57.0 & 3.4 & 2.5 & 2.0 & 3.2 & 3.0 \\
\hline China & Emerging & 28.8 & 1.5 & 2.1 & 1.2 & 2.8 & 4.0 \\
\hline Colombia & Developing & 16.5 & 3.3 & 3.1 & 1.2 & 3.1 & 3.9 \\
\hline Croatia & Emerging & 23.3 & 3.1 & 4.6 & 4.0 & 4.1 & 3.4 \\
\hline Egypt & Developing & 22.9 & 3.0 & 3.6 & 2.9 & 4.5 & 4.4 \\
\hline Hungary & Emerging & 20.4 & 2.6 & 4.2 & 3.6 & 3.4 & 3.7 \\
\hline India & Developing & 28.0 & 1.4 & 2.2 & 1.8 & 2.4 & 4.8 \\
\hline Indonesia & Developing & 17.7 & 2.3 & 2.9 & 1.5 & 2.4 & 4.4 \\
\hline Iran & Developing & 17.5 & 4.1 & 4.0 & 3.4 & 4.0 & 4.8 \\
\hline Malaysia & Developing & 3.5 & 1.6 & 2.4 & 1.7 & 2.4 & 2.8 \\
\hline Mexico & Developing & 18.2 & 2.9 & 3.0 & 1.8 & 2.9 & 4.0 \\
\hline Morocco & Developing & 14.5 & 3.3 & 2.9 & 2.9 & 4.2 & 4.2 \\
\hline Peru & Developing & 14.9 & 3.1 & 3.7 & 2.0 & 3.4 & 4.6 \\
\hline Poland & Emerging & 27.7 & 2.2 & 3.4 & 3.1 & 3.7 & 3.0 \\
\hline Qatar & Developing & 22.8 & 2.4 & 1.9 & 1.7 & 2.2 & 1.9 \\
\hline Russia & Emerging & 5.4 & 3.7 & 3.9 & 3.7 & 3.7 & 3.3 \\
\hline Saudi Arabia & Developing & 12.9 & 2.9 & 3.0 & 2.3 & 4.1 & 2.9 \\
\hline Slovenia & Emerging & 33.2 & 3.0 & 3.5 & 3.8 & 3.2 & 2.5 \\
\hline South Africa & Developing & 22.0 & 2.7 & 3.4 & 3.0 & 3.6 & 2.9 \\
\hline Thailand & Developing & 17.1 & 2.4 & 3.1 & 1.8 & 3.1 & 3.3 \\
\hline Turkey & Developing & 30.8 & 2.4 & 3.3 & 2.2 & 2.9 & 3.4 \\
\hline
\end{tabular}

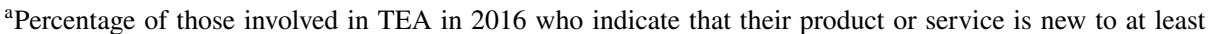
some customers AND that few/no businesses offer the same product

$2=$ some, $3=$ none). For process innovation, GEM asks respondents "Were the technology or procedures available more than a year ago?" $(1=$ no, $2=$ yes but not before five years ago, $3=$ yes). We reverse score the responses and combine answers to these two questions.

\subsubsection{Perceived entrepreneurial ability}

Following previous research (Arenius \& Minniti, 2005; Bayon et al., 2015), we measure PEA using a GEM binary self-reported question. GEM asks respondents whether they believe they have the knowledge, skill, and experience required to start a new business $(1=$ yes, $0=$ no).

\subsubsection{Entrepreneurial motivation}

To capture entrepreneurial motivation, we used the following question from GEM: "What is your motive for being involved in total early stage entrepreneurship". Responses include: 
increase income, independence, maintain income, or because they had no other option. We consider the first two responses are considered pull motivations whereas the last two are push motivation (Hessels et al., 2008). Using responses to this question, we developed a binary measure with a value of 1 for those with pull and 0 for those with push motivation.

\subsubsection{Perceived entrepreneurial opportunity}

Consistent with our arguments, to measure PEO, we need to capture the individuals' perception regarding external opportunities (Chang et al., 2012). To do so, we used the following question on opportunity perception from GEM which has been used by similar prior studies (e.g., Roper \& Scott, 2009). The survey asks the respondents whether in the next six months, there would be good opportunities for starting a business in the area where they lived. This measure is a binary variable $(1=$ yes, $0=$ no $)$.

\subsubsection{Innovation barriers}

The second group of independent variables are country-level innovation barriers constructs. We defined each innovation barrier variable based on Caiazza (2016) innovation diffusion barriers framework.

General barriers. General barriers are divided into legal, economic, and cultural groups. We measure the legal dimension by averaging seven GEM NES questions that asses the effectiveness of a country's government policies aimed at entrepreneurship including the support for new firms at local and national governments, and fairness and predictability of taxes $\left(\alpha_{1}=0.90\right)$. Similarly, to measure the economic dimension, we average the responses to eight questions in the GEM NES that assess availability of various funding sources for new ventures including venture capitalist, angel investors, informal investors, and banks $\left(\alpha_{2}\right.$ $=0.91)$. The cultural dimension is measured as the average of five items including degree to which the national culture encourages risk taking, creativity, and innovativeness $\left(\alpha_{3}=\right.$ 0.97).

Supply side barriers. To measure the supply-side barriers of innovation, we combined the average scores of six questions about the quality of educational system-including primary, secondary, and university level—and R\&D transfer including six questions about the extent to which national research and development leads to new commercial opportunities and is available to SMEs from GEM NES $\left(\alpha_{4}=0.93\right)$.

Demand side barriers. We draw our measures of the demand-side from WEF Global Competitiveness Report database. Following Caiazza (2016) framework, we combined six questions from infrastructure, goods market efficiency, and technological readiness $\left(\alpha_{5}=\right.$ $0.73)$. We also ran a confirmatory factor analysis to validate our measure $\left(\mathrm{KMO}=0.70 ; \chi^{2}\right.$ $=81.74 ; p \leq 0.000)$.

Appendix A summarizes information on individual items used to calculate each innovation barrier. The original questions are framed such that higher values reflect a lower barrier. We reverse score the responses.

\subsubsection{Control variables}

At individual-level, prior research shows that age has an impact on individuals' motivation for pursuing an entrepreneurial activity (Singh \& Verma, 2001). Additionally, age has been shown to affects entrepreneurial growth aspiration (Kolvereid, 1992). We also controlled 
for the gender of respondents since the career psychology literature provides a substantial amount of evidence that gender is a significant variable in pursuing entrepreneurial activities (Carter et al., 2001). Additionally, we controlled for respondents' level of income since the level of wealth affects engagement in innovation (Lim et al., 2016). We also controlled for entrepreneurial social capital. which is known to influence entrepreneurship particularly in countries exhibiting voids in their formal institutions (De Clercq et al., 2010). Appendix $\mathrm{B}$ provides the details of the individual level control variables in the study.

At the country-level, we controlled for GDP per capita adjusted for purchasing power parity since the level of national wealth can be associated with entrepreneurship (Acs et al., 2008; Estrin et al., 2016). Similarly, since the change in national wealth may also affect IE, we controlled for GDP growth during the previous year of GEM survey. Additionally, since unemployment is among the main factors that steer individuals towards imitative entrepreneurship, we controlled for unemployment rate (Verheul et al., 2002).

\subsection{Analytical technique}

Given the nested, multilevel nature of our data, we tested our hypotheses using hierarchical linear modeling (HLM) analyses with the HLM 8.0 program (Raudenbush \& Bryk, 2002). In simple regression equations all data points (i.e., entrepreneurs) are treated as independent variables. Consequently, differences among higher level variables (i.e., countries) can potentially be obscured. On the other hand, fitting a multi-level model has at least two advantages over a single-level regression analysis. First, a multi-level model decreases type one error due to acknowledging the existence of different levels of analysis (Hofmann, 1997). Second, it offers an improvement over aggregating data to higher levels, known as the ecological fallacy (Peterson et al., 2012).

To run our multi-level model, we first created the null model to check for a significant variance between level two variables. Null model is the basis for calculating intraclass correlation coefficient (ICC) and deviance statistics. Accordingly, we entered binary variables (uncentered), other level one variables (group-mean-centered), and country level variables (grand-mean centered) (Hofmann \& Gavin, 1998). Further we tested the relationship between the individual-level and country-level predictors of IE using random coefficient regression, intercepts-as-outcomes, and slopes-as-outcomes models (Raudenbush, \& Bryk, 2002).

\section{Results}

Tables 2 and 3 display the descriptive statistics and correlation matrix for individual-level and country-level variables, respectively. Table 3 indicates relatively high correlations between our country-level variables. Following similar research (e.g., Bowen \& De Clercq, 2008; De Clercq et al., 2010), we used the condition number of the data matrix, as a more accurate approach for detecting collinearity. Collinearity issue may be a problem when condition number value exceeds 30 (Belsley et al., 1980). The condition number of our data matrix is 4.34 , indicating that collinearity is not an issue as suggested by the simple bivariate correlation.

To test our proposed model including direct and moderation effects, as shown in Table 4, we first entered all individual level control variables in Model 1. Model 2 adds the three entrepreneurial competencies. Model 3 adds innovation barriers and country level 


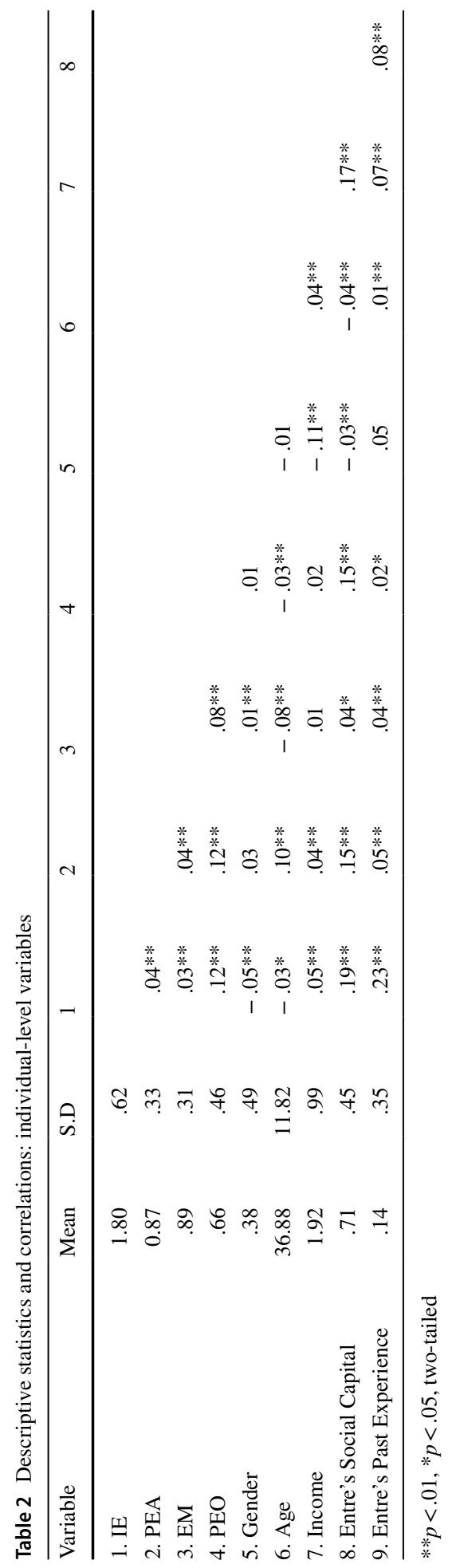


Table 3 Descriptive statistics and correlations: country-level variables

\begin{tabular}{|c|c|c|c|c|c|c|c|c|c|}
\hline Variable & Mean & S.D & 1 & 2 & 3 & 4 & 5 & 6 & 7 \\
\hline 1. GDP Per Capita (thousands) & 13.62 & 13.76 & & & & & & & \\
\hline 2. GDP Growth & 3.07 & 3.13 & $-.16^{* *}$ & & & & & & \\
\hline 3. Unemployment Rate & 7.10 & 4.71 & $-.29 * *$ & $-.05^{*}$ & & & & & \\
\hline 4. Legal (General barrier) & 3.20 & .63 & $-.09 * *$ & -.02 & $.39 * *$ & & & & \\
\hline 5. Economic (General barrier) & 2.90 & .68 & .02 & $-.20 * *$ & -.23 & $.29 * *$ & & & \\
\hline 6. Cultural (General barrier) & 2.50 & .73 & $-.07 *$ & $.05^{* *} *$ & $.55^{* *}$ & $.51 * *$ & $.33 * *$ & & \\
\hline 7. Supply-side barriers & 3.24 & .50 & $.21 * *$ & -.02 & $.38 * *$ & $.55 * *$ & $.51 *$ & $.61 * *$ & \\
\hline 8. Demand-side barriers & 3.48 & .76 & $-.62 * *$ & $.55^{* *}$ & $.13^{*}$ & $.26 * *$ & $-.09 * *$ & $.04 * *$ & $.07 * *$ \\
\hline
\end{tabular}

$* * p<.01, * p<.05$, two-tailed

Table 4 Results of hierarchical linear modeling analyses: main and interactive effects

\begin{tabular}{|c|c|c|c|c|}
\hline Variables & Model (1) & Model (2) & Model (3) & Model (4) \\
\hline \multicolumn{5}{|l|}{ Individual Level Controls } \\
\hline Gender $($ female $=1)$ & .03 & .02 & .02 & .03 \\
\hline Age & $-.01 * * *$ & $-.01 * *$ & $-.01 * *$ & $-.02 * *$ \\
\hline Income & $.02 *$ & .02 & .02 & -.08 \\
\hline Social capital & $.04 * *$ & $.03 * *$ & $.04 * *$ & $.03 * *$ \\
\hline Past experience & $.12 * * *$ & $12 * * *$ & $.14 * * *$ & $.14 * * *$ \\
\hline \multicolumn{5}{|l|}{ Country Level Variables } \\
\hline GDP Growth & & & $-.01 * *$ & $-.01 * *$ \\
\hline GDP Per Capita & & & .01 & .01 \\
\hline Unemployment Rate & & & $.02 * *$ & $.02 * *$ \\
\hline General legal barriers & & & $-.27 * * *$ & $-.35 * * *$ \\
\hline General economic barriers & & & $-.08 *$ & $-.21^{*}$ \\
\hline General cultural barriers & & & $-.17 *$ & $-.13^{*}$ \\
\hline Supply-side barriers & & & $-.16^{* * *}$ & $-.30 * * *$ \\
\hline Demand-side barriers & & & $-.20 * * *$ & $-.15^{* * * *}$ \\
\hline \multicolumn{5}{|l|}{ Individual Level Predictors } \\
\hline PEA & & $.08 * * *$ & $.07 * * *$ & $.34 * * *$ \\
\hline EM & & $.14 * * *$ & $.13 * * *$ & $1.18 * * *$ \\
\hline PEO & & $1.02 * * *$ & $.98 * * *$ & $.64 * * *$ \\
\hline \multicolumn{5}{|l|}{ Cross Level Interactions } \\
\hline $\mathrm{EM} \times$ General legal barriers & & & & $.29 * * *$ \\
\hline $\mathrm{EM} \times$ General economic barriers & & & & $.12 * * *$ \\
\hline $\mathrm{EM} \times$ General cultural barriers & & & & $-.08^{*}$ \\
\hline PEA $\times$ Supply-side barriers & & & & $.18^{* *}$ \\
\hline $\mathrm{PEO} \times$ Demand-side barriers & & & & $.14 * * *$ \\
\hline Log-likelihood & 1168.14 & 1000.62 & 925.24 & 901.84 \\
\hline Model fit test $\left(\chi^{2}\right)$ & 0.000 & 0.000 (against 1) & 0.000 (against 2) & 0.000 (against 3) \\
\hline
\end{tabular}

$* p<.05, * * p<.01, * * * p<001$ 
controls and Model 4 adds the interaction terms between individual-level competencies and general, supply-side, and demand-side innovation barriers. Among control variables, age (negatively), entrepreneur's experience and social capital are associated with IE. Gender (female) and income are not a significant predictor for IE. Further, to test the direct effects, we used a random coefficient regression model and added individual-level control variables along with three main independent variables (i.e., PEA, EM, and PEO). As shown in Table 4, IE is significantly and positively associated with PEA, EM, and PEO across models 2-4 $(p<0.001)$. Using the Hypothesis testing feature in HLM 8, we compared Model 2 deviance with that of Null model and Model 1. The significant amount of drop in the deviance indicates a better fit.

Using intercepts as outcomes for Model 3, we first added country-level control variables. At the country-level, GDP Growth (negatively) and unemployment rate are significantly relevant to IE whereas GDP per capita was not a significant driver. According to Model 3, a country's general (legal, economic, and cultural), supply-side, and demand-side barriers are negatively associated with IE.

With respect to testing study's Hypotheses, we used a slopes as-outcomes model (Table 4, fourth column; Hofmann, 1997). The positive significant interaction between general legal barriers and EM indicates that the relationship between EM and IE is stronger for a higher general legal barrier in support of Hypothesis $1 \mathrm{a}(\beta=0.29 ; p<0.001)$. Similarly, results show that general economic barriers are a positive, significant moderator of the relationship between EM and IE as predicted by Hypothesis $1 \mathrm{~b}(\beta=0.12 ; p<0.001)$. However, contrary to Hypothesis 1c, results show a significant negative interaction between EM and general cultural barriers which indicates that the positive relationship between EM and IE is stronger when the cultural barriers are lower, rather than higher $(\beta=-0.08 ; p<0.01)$. Thus, Hypothesis 1 receives partial support.

Our results also offer strong support for Hypothesis 2 predicting that when supply-side barriers are higher the relationship between PEA and IE is stronger $(\beta=0.18 ; p<0.01)$. Further, the positive interaction between demand side barriers and PEO $(\beta=0.14$; $p<0.001$ ), provides support for Hypothesis 3 which predicts that the relationship between PEO and IE is stronger when demand-side barriers are higher. For the fourth model, we observed a significant drop in the deviance compared to the Null model and Models 1-3. Thus, we can conclude that adding the interaction effects has significantly improved the model fit.

To make the evaluation of interactions easier, we plotted the moderating effects in Fig. 1 to display the relationship between IE and three entrepreneurial competencies for countries with strong/week innovation barriers. As illustrated, the direct relationships of entrepreneurial competencies and IE are stronger (the lines are steeper) in the presence of strong (vs. weak) barriers.

\subsection{Additional tests}

In order to explore the robustness of our results, we conducted a range of robustness checks. First, to exclude the potential time element of the three individual level independent variables, we ran an additional test. We set PEA as independent variable and the sum of EM and PEO as dependent variable and collected the residuals. Similarly, we regressed EM on PEO and collected the residuals. Finally, we replaced PEA with first step's collected residuals and EM with step 2 residuals and reran our model. Although the magnitude of coefficients changed, the robustness test did not affect the significance of our 
(a) PEA and supply-side barriers

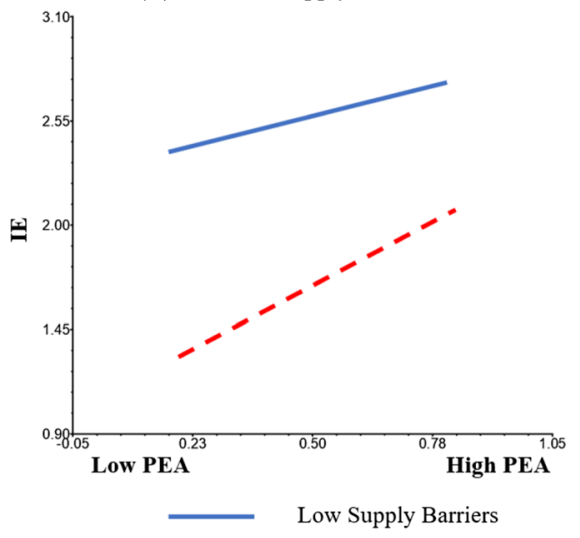

- - - High Supply Barriers

(c) EM and general legal barriers

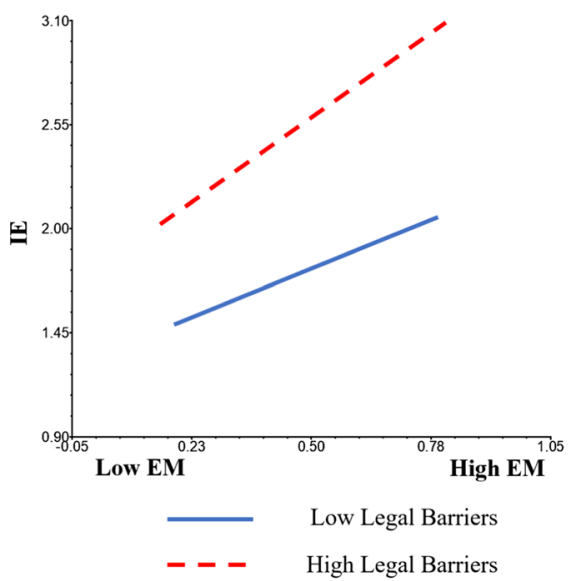

(b) PEO and demand-side barriers

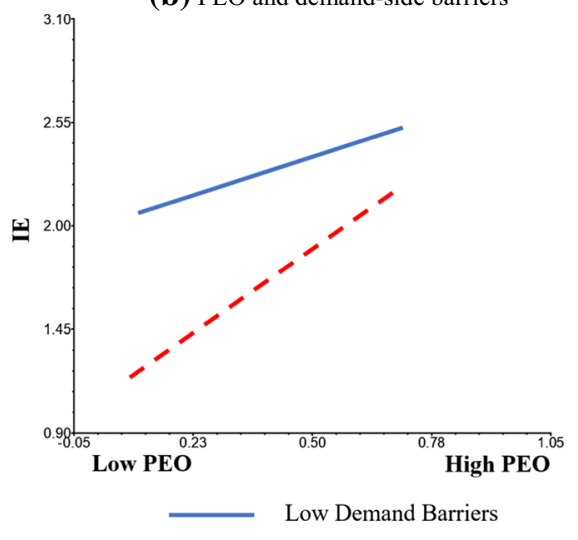

- - - High Demand Barriers

(d) EM and general economic barriers

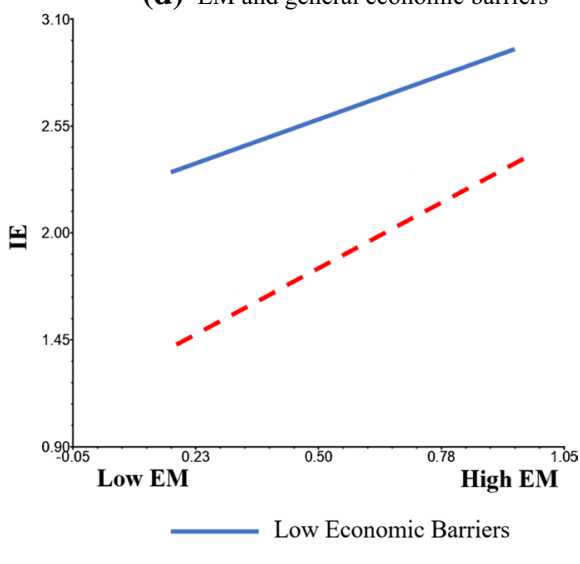

- - - High Economic Barriers

Fig. 1 Moderating Effects of Innovation Barriers on the Impact of Entrepreneurial Competencies on Innovative Entrepreneurship (IE)

results. Second, we used an alternative binary proxy to measure EM. Entrepreneurs that indicated they were involved in a start-up to take advantage of a business opportunity were considered motivated (i.e., scored "1") and others (i.e., involved because they have no better choices for work) considered as not motivated (i.e. scored "0") (Acs, 2006). The new measurement did not cause any significant change in our results.

Further, to exclude potential multicollinearity from our fourth model, we replicated our analysis by adding each dimension of innovation barriers to the model individually. Although it led to different amounts for moderating effects, the significance of the results remained unchanged. Furthermore, to account for the level of IE in developing versus emerging economies, we include a dummy variable $(1=$ developing economy; $0=$ emerging economy). We find this dummy variable significant in predicting the level of innovative venture creation. However, adding the variable to our model did not change the significance of our interaction effects. Finally, considering the effects of other national level 
variables, we added more control variables including government expenditure, age structure of population, ethnical diversity, religious diversity, and government tax burden on individuals as well as on corporations (Bowen \& De Clercq, 2008). Adding these control variables did not change the pattern of our main findings.

\section{Discussion}

Policymakers and scholars alike have shown an increasing interest in discovering different aspects of the relationship between entrepreneurship and economic development. Amid critical and debates on the potential positive outcomes of entrepreneurship, many acknowledge that the outmost benefits from entrepreneurship are mainly generated by innovative, high-growth ventures (Bosma et al., 2018). Given the increasing desire for economic growth in EDEs, this study seeks to advance the literature on stimulating entrepreneurship in these countries by outlining the essential drivers of IE. We developed a multilevel model to explore how individual competencies can bridge the institutional voids relevant to innovative new venture creation and hypothesized that the beneficial effects of entrepreneurial competencies on IE would be stronger when innovation barriers are higher. Our results provide support for two of the three innovation barriers and partial support for one barrier. First, our results indicate that the relationship between IE and PEA is stronger for higher supply-side innovation burdens. Put simply, in EDEs with weak and inadequate entrepreneurial education, inefficient process to access and transfer knowledge, and high cost of adopting new technologies, skilled, knowledgeable, and expert entrepreneurs appear to be more likely to start an innovative venture than their counterparts do in the absence of such barriers. Second, we find that the relationship between PEO and IE is stronger in countries where demand-side facilitators of innovation (e.g., transportation and communication infrastructure, customer responsiveness mechanisms, and buyers demand sophistication) are underdeveloped. Overall, our findings with regard to supply- and demand-side barriers of innovation contribute to research in EDEs by clarifying the substitution effect between individual factors and macro-level burdens, particularly with regard to a country's propensity for IE.

Our results indicate that the interaction effects between general barriers of innovation (legal, economic, and cultural) and EM are more intricate than our a priori theoretical model suggested. Specifically, we find that entrepreneurs tend to rely heavier on their pull motivations when encounter general legal barriers (i.e., weak or unsupportive government policies pertaining to new firms) and general economic barriers (i.e., insufficient funding sources for new and growing firms). These two together contribute to literature by uncovering the strong role of EM in bridging the legal and financial gaps in developing countries, particularly in the case of innovative new ventures.

However, contrary to our expectations, the relationship between EM and IE is stronger for lower rather than higher general cultural barriers of innovation. That is, EM and supporting social systems appear to exert complementary rather substitutive impact on IE. That reveals the significance and power of the normative institutions (i.e., culture). Although it was contrary to what we predicted, we suggest a possible interpretation that considers the informal governance mechanisms (e.g., social and kinship ties) in resource mobilization of entrepreneurial ventures a nonsubstitutable element in EDE contexts (Foo et al., 2020). Informal governance is derived from embeddedness in ongoing social relations and refers to relational arrangements that are built on trust, reciprocity, and identity 
(Bradach \& Eccles, 1989). Given the lack of effective formal governance mechanisms in EDEs (e.g., weak IPR, political instability, unreliable judiciary system), entrepreneurs rely significantly on informal governance for resource mobilization actions. Therefore, it is burdensome, even for individuals with strong pull motives, to overcome the cultural stigmas in EDEs and engage in high-risk innovative ventures.

\subsection{Theoretical implications}

Emerging economies are shown to have higher rates of entrepreneurship, yet lag behind economically (Bosma \& Levie, 2010). In line with extent literature that general entrepreneurship outcomes are not always promising (e.g., Henrekson \& Sanandaji, 2020; Shane, 2009), we go beyond the traditional focus on the new venture creation in EDEs (De Clercq et al., 2010; Lim et al., 2016; Urbano \& Alvarez, 2014) and analyze drivers of innovative ventures. We apply an interactionist approach (Welter \& Smallbone, 2011) and develop an integrated multilevel framework to study IE which despite its importance, has received limited attention. To our knowledge, this is one of the first attempts to respond to calls for multilevel, cross-country assessment of IE particularly in the context of developing and emerging countries (Block et al., 2017). Our framework illustrates how certain individual attributes can substitute for the voids and barriers in institutions. It also reveals the mechanisms through which the barriers manifest their impact interacting with individual-level attributes. We find that entrepreneurs with higher levels of ability and perceived opportunity as well as those with a higher pull motive are in fact more likely to engage in IE, in settings that represent more institutional voids and barriers. Our study confirms the "institutional entrepreneurs" notion in that it is possible to start innovative ventures even in countries with rampant institutional voids (Tracey \& Philips, 2011) and further extends it by offering evidence that helping individuals to acquire entrepreneurial competencies can promote IE by mitigating the negative effects of innovation barriers. Hence, we move beyond the current theme in the literature that improving macro-level institutions is the major solution for unfavorable ecosystems (Chowdhury et al., 2019).

Furthermore, we contribute to better understanding of entrepreneurial competencies serving as a mechanism to offset the effect of innovation barriers on IE. Based on our findings, innovation barriers (e.g., supply-side) did not affect IE for individuals who had higher PEA.

Therefore, we suggest that the cognitive structures resulted from entrepreneurs' confidence in their ability and skills facilitate innovative venture creation. This finding adds to insights about why and how entrepreneurial ability unfolds its effect in EDEs. Additionally, given that confidence in abilities and skills can be strengthen through entrepreneurial training, our findings also contribute to developing a comprehensive theory of entrepreneurship training.

Current literature acknowledges the influence of individuals motivation, as one of the important human agency factors, on entrepreneurship (e.g., Shane et al., 2003); or argues that country-level prevalence of certain motivations (e.g., increasing wealth) corresponds with certain entrepreneurial outcomes such as growth- or export-orientation new ventures (e.g., Hessels et al., 2008). We add to this stream of research by highlighting the intricate interactions between individuals' motivations and the institutional settings in stimulating different entrepreneurial aspirations. That is, when government regulations are ineffective and cumbersome and funding sources (e.g., equity, debt, informal and angel investors, and 
IPO) are insufficient for new firms, individuals with strong pull motives thrive in creating innovative ventures.

Further, we contribute to the literature by particularly focusing on EDEs as the context of our study which has been called for by prior studies (Foo et al., 2020; Webb et al., 2019). Our findings suggest that the joint effects of micro- and macro-level configurations offer more explanatory power than the examination of entrepreneur competencies alone does. Given the lack of well-developed formal governance mechanisms and the salient role of informal governance in EDEs (e.g., relational contracts, trust), we argue that entrepreneurial competencies become more instrumental in EDEs when individuals involve in establishing innovative ventures are guided by market logics (i.e., economic rationality; Clough et al., 2019). This sheds light on the conflicting findings in prior literature with regard to the relationship between entrepreneurship and institutions in emerging countries (Wright \& Hitt, 2017).

\subsection{Policy implications}

As a broad implication, policymakers in EDEs should pay more attention to the entrepreneurial competencies as a means of developing innovative new ventures to facilitate economic development, particularly before fully transitioning towards a salient institutional environment. For instance, according to our findings, higher levels of entrepreneurial perceived abilities can make up for supply-side barriers in developing innovative ventures. In developed countries, "entrepreneurship" as a filed of study has long been a prominent aspect of social science education and top-tier universities and R\&D laboratories act as the incubators of a steady flow of novel ideas. EDEs also need to arrange the establishment of a wider range of training for existing and aspiring entrepreneurs. While removing the supply-side barriers and offering a solid institutional foundation for entrepreneurs can take a long time and resources, offering targeted educational support can be a short/mid-term remedy. Given that the resulted mental models and cognitive structures of entrepreneurship training (Bischoff et al., 2020), implementation of a wide ranging entrepreneurial training provides policy makers and practitioners in EDEs with a more sustainable and less costintensive solution for enhancing IE in the presence of innovation barriers.

Furthermore, our result reveals the dominance of national culture over individual motivations and demonstrates that unsupportive culture is the only institutional barrier in our framework that cannot be overcome by entrepreneurial attributes. Hence, to promote IE, policymakers should cultivate supportive norms and culture toward innovativeness and entrepreneurship. Although we acknowledge the stability of the culture (Stephan \& Uhlaner, 2010), community builders and small business supporting organizations in EDEs can adopt initiatives to increase the perceived desirability of IE. For instance, promoting successful entrepreneurs as positive role models in meetups and informal forums, and pitch competitions at community-level to recognize and promote innovative entrepreneurs, allow individuals in societies to form a more positive attitude towards IE.

\subsection{Limitations and future research}

Our study is not without limitation which we believe set the stage for future research. First, while we acknowledge many advantages to using GEM data (e.g., international scope, large sample size), we faced some limitations using this date base. For instance, our individuallevel drivers, PEA, EM and PEO, are binary variables which may limit the explanatory 
power of our multi-level framework. Additional research may use multi-dimensional proxies to capture entrepreneurial ability, motivation, and opportunity more comprehensively to confirm our results. Further, like other research using GEM dataset, reverse causality is a concern due to the cross-sectional nature of the data (Estrin et al., 2016). That is, entrepreneurs in EDEs, where the institutional environment tend to be in flux, also might influence the innovation barriers which is very difficult and unlikely. Nonetheless, we used lagged data for our national level variables. Longitudinal investigations of the interactions among individual factors, innovation barriers, and IE can strengthen and extend our findings. We also acknowledge that GEM uses specific questions for measuring innovativeness. The interpretation of different items may vary across cultures. Future works may address this concern by using different theoretical frameworks that allow for integration of cultural variables.

Second, contrary to what we predicted, we observed a negative interaction between a country's general cultural barriers and EM. Although we suggest a possible interpretation that may help to disentangle the mechanisms by which macro-level culture interact with EM to bring about IE, we acknowledge that the provided explanations are rather speculative. Thus, more comprehensive research should further assess entrepreneurs' motivations about specific types of entrepreneurial activities and their relative power compared to societal culture. Therefore, we echo the call by recent entrepreneurship literature for more research on the informal mode of resource-mobilization (i.e., governance based on identity and trust) in EDEs. (Clough et al., 2019).

Third, we focus on EDEs as the context of our study due to dearth of relevant research in this context and the fact that promoting the right kind of entrepreneurship (i.e., IE) can be a crucial solution to urgently needed economic growth in these countries. Comparative studies using data from various types of economies across the world can shed more light on solutions that can work in different institutional settings. Relevant to this limitation, future work can also examine how different entrepreneurial competencies can enable entrepreneurs to manage the destructive effects of institutional voids in EDEs. For example, compared with the counterparts in developed countries, entrepreneurs with higher socioeconomic status in EDEs may confront a higher risk of government expropriation while entrepreneurs with political connections can alleviate this risk (Zhou et al., 2020).

\section{Conclusion}

To conclude, we adopt an interactionist perspective and show that individual (i.e., personality traits and behavioral characteristics) and environmental factors interact in predicting IE in EDEs. We develop a multilevel framework drawing from AMO and innovation barriers models that explicate the nuanced relationship between micro- and macro-level factors and IE. We posit that entrepreneurial competencies (PEA, EM, and PEO) are primary antecedents of IE and the beneficial role of such competencies for IE will in fact, be more pronounced in emerging countries where the institutions are not solid and often include voids. Furthermore, our study is among the first to examine the combined role of entrepreneurial competencies and macro-barriers in stimulating innovative new venture creation in EDEs. We contribute to the extant literature in this domain by theorizing that these two sets of factors might substitute for one another and by providing empirical evidence for that notion from a sample of 24 countries. 


\section{Appendix A: Measurement items for innovation barriers}

\begin{tabular}{ll}
\hline Barrier type & Measure \\
\hline General legal & In my country, Government policies (e g, public procurement) consistently favor new \\
firms & In my country, the support for new and growing firms is a high priority for policy at the \\
national government level \\
In my country, the support for new and growing firms is a high priority for policy at the \\
local government level \\
In my country, new firms can get most of the required permits and licenses in about a \\
week \\
In my country, the amount of taxes is NOT a burden for new and growing firms \\
In my country, taxes and other government regulations are applied to new and growing \\
firms in a predictable and consistent way \\
In my country, coping with government bureaucracy, regulations, and licensing \\
requirements it is not unduly difficult for new and growing firms
\end{tabular}

General economic In my country, there is sufficient equity funding available for new and growing firms In my country, there is sufficient debt funding available for new and growing firms

In my country, there are sufficient government subsidies available for new and growing firms

In my country, there is sufficient funding available from informal investors (family, friends and colleagues) who are private individuals (other than founders) for new and growing firms

In my country, there is sufficient funding available from professional Business Angels for new and growing firms

In my country, there is sufficient funding available from venture capitalists for new and growing firms

In my country, there is sufficient funding available through initial public offerings (IPOs) for new and growing firms

In my country, there is sufficient funding available through private lenders' funding (crowdfunding) available for new and growing firms

General cultural In my country, the national culture is highly supportive of individual success achieved through own personal efforts

In my country, the national culture emphasizes self-sufficiency, autonomy, and personal initiative

In my country, the national culture encourages entrepreneurial risk-taking

In my country, the national culture encourages creativity and innovativeness

In my country, the national culture emphasizes the responsibility that the individual (rather than the collective) has in managing his or her own life

Supply-side In my country, teaching in primary and secondary education encourages creativity, self-sufficiency, and personal initiative

In my country, teaching in primary and secondary education provides adequate instruction in market economic principles

In my country, teaching in primary and secondary education provides adequate attention to entrepreneurship and new firm creation

In my country, Colleges and universities provide good and adequate preparation for starting up and growing new firms

In my country, the level of business and management education provide good and adequate preparation for starting up and growing new firms 


\begin{tabular}{|c|c|}
\hline Barrier type & Measure \\
\hline & $\begin{array}{l}\text { In my country, the vocational, professional, and continuing education systems provide } \\
\text { good and adequate preparation for starting up and growing new firms }\end{array}$ \\
\hline & $\begin{array}{l}\text { In my country, new technology, science, and other knowledge are efficiently transferred } \\
\text { from universities and public research centers to new and growing firms }\end{array}$ \\
\hline & $\begin{array}{l}\text { In my country, new and growing firms have just as much access to new research and } \\
\text { technology as large, established firms }\end{array}$ \\
\hline & In my country, new and growing firms can afford the latest technology \\
\hline & $\begin{array}{l}\text { In my country, there are adequate government subsidies for new and growing firms to } \\
\text { acquire new technology }\end{array}$ \\
\hline & $\begin{array}{l}\text { In my country, the science and technology base efficiently supports the creation of } \\
\text { world-class new technology-based ventures in at least one area }\end{array}$ \\
\hline & $\begin{array}{l}\text { In my country, there is good support available for engineers and scientists to have their } \\
\text { ideas commercialized through new and growing firms }\end{array}$ \\
\hline \multirow[t]{6}{*}{ Demand-side } & $\begin{array}{l}\text { How do you assess the general state of infrastructure (e.g., transport, communications, } \\
\text { and energy) in your country? }[1=\text { extremely underdeveloped-among the worst in } \\
\text { the world; } 7=\text { extensive and efficient-among the best in the world] }\end{array}$ \\
\hline & $\begin{array}{l}\text { In your country, how well do companies treat customers? }[1=\text { poorly }- \text { mostly indiffer- } \\
\text { ent to customer satisfaction; } 7=\text { extremely well }- \text { highly responsive to customers and } \\
\text { seek customer retention] }\end{array}$ \\
\hline & $\begin{array}{l}\text { In your country, on what basis do buyers make purchasing decisions? }[1=\text { based solely } \\
\text { on the lowest price; } 7=\text { based on sophisticated performance attributes }]\end{array}$ \\
\hline & Percentage of individuals using the Internet \\
\hline & Internet bandwidth \\
\hline & Mobile-broadband subscriptions \\
\hline
\end{tabular}

\section{Appendix B: Control variables used in study}

\begin{tabular}{|c|c|c|c|}
\hline \multicolumn{3}{|c|}{ Individual-level control variables } & \multirow{2}{*}{$\frac{\text { Data source }}{\text { GEM }}$} \\
\hline Gender & \multicolumn{2}{|c|}{ Respondent's sex $(0=$ male; $1=$ female $)$} & \\
\hline Age & \multicolumn{2}{|c|}{ Respondent's age } & \\
\hline Income & \multicolumn{2}{|r|}{$\begin{array}{l}\text { The upper- }(=3) \text {, middle- }(=2) \text {, or lower- }(=1) \text { third of the income distribu- } \\
\text { tion in the country }\end{array}$} & GEM \\
\hline Social capital & \multicolumn{2}{|r|}{$\begin{array}{l}\text { Respondents were asked whether personally knew someone who had started } \\
\text { a business in the past two years }(0=\text { No; } 1=\text { Yes })\end{array}$} & GEM \\
\hline Past experience & \multicolumn{2}{|r|}{$\begin{array}{l}\text { Respondents were asked whether they have sold, closed or shutdown a busi- } \\
\text { ness over the last } 12 \text { months }\end{array}$} & \\
\hline \multicolumn{3}{|c|}{ Country-level Control Variables } & Data source \\
\hline GDP per capita & & The natural log of GDP per capita in the previous year of the survey & World Bank \\
\hline GDP growth & & $\begin{array}{l}\text { GDP growth from the previous year of the survey to the year of the } \\
\text { survey (annual \%) }\end{array}$ & World Bank \\
\hline Unemployment & rate & Total labor force (annual \%) & World Bank \\
\hline
\end{tabular}


Funding Open access funding provided by Università Parthenope di Napoli within the CRUI-CARE Agreement.

Open Access This article is licensed under a Creative Commons Attribution 4.0 International License, which permits use, sharing, adaptation, distribution and reproduction in any medium or format, as long as you give appropriate credit to the original author(s) and the source, provide a link to the Creative Commons licence, and indicate if changes were made. The images or other third party material in this article are included in the article's Creative Commons licence, unless indicated otherwise in a credit line to the material. If material is not included in the article's Creative Commons licence and your intended use is not permitted by statutory regulation or exceeds the permitted use, you will need to obtain permission directly from the copyright holder. To view a copy of this licence, visit http://creativecommons.org/licenses/by/4.0/.

\section{References}

Acs, Z. (2006). How is entrepreneurship good for economic growth? Innovations: Technology, Governance, Globalization, 1(1), 97-107.

Acs, Z., Åstebro, T., Audretsch, D., \& Robinson, D. T. (2016). Public policy to promote entrepreneurship: A call to arms. Small Business Economics, 47(1), 35-51.

Acs, Z. J., Desai, S., \& Hessels, J. (2008). Entrepreneurship, economic development and institutions. Small Business Economics, 31(3), 219-234.

Aldrich, H. E., \& Fiol, C. M. (1994). Fools rush in? The institutional context of industry creation. Academy of Management Review, 19(4), 645-670.

Aldrich, H. E., \& Martinez, M. A. (2001). Many are called, but few are chosen: An evolutionary perspective for the study of entrepreneurship. Entrepreneurship Theory and Practice, 25(4), 41-56.

Alexander, E. A. (2012). The effects of legal, normative, and cultural-cognitive institutions on innovation in technology alliances. Management International Review, 52(6), 791-815.

Arenius, P., \& Minniti, M. (2005). Perceptual variables and nascent entrepreneurship. Small Business Economics, 24(3), 233-247.

Autio, E. (2005). GEM report on high-expectation entrepreneurship. Babson College and London Business School.

Baum, J. R., \& Locke, E. A. (2004). The relationship of entrepreneurial traits, skill, and motivation to subsequent venture growth. Journal of Applied Psychology, 89(4), 587-598.

Baum, J. R., Locke, E. A., \& Smith, K. G. (2001). A multi-dimensional model of venture growth. Academy of Management Journal, 44(2), 292-303.

Baumol, W. J. (1996). Entrepreneurship: Productive, unproductive, and destructive. Journal of Business Venturing, 11(1), 3-22.

Baumol, W. J., Litan, R. E., \& Schramm, C. J. (2007). Good capitalism, bad capitalism, and the economics of growth and prosperity. Yale University Press.

Bayon, M. C., Vaillant, Y., \& Lafuente, E. (2015). Initiating nascent entrepreneurial activities: The relative role of perceived and actual entrepreneurial ability. International Journal of Entrepreneurial Behavior \& Research, 21(1), 27-49.

Belsley, D. A., Kuh, E., \& Welsch, R. E. (1980). Regression diagnostics: Identifying influential data and sources of collinearity. Wiley.

Bischoff, K. M., Gielnik, M. M., \& Frese, M. (2020). When capital does not matter: How entrepreneurship training buffers the negative effect of capital constraints on business creation. Strategic Entrepreneurship Journal, 14(3), 369-395.

Block, J. H., Fisch, C. O., \& Van Praag, M. (2017). The Schumpeterian entrepreneur: A review of the empirical evidence on the antecedents, behaviour and consequences of innovative entrepreneurship. Industry and Innovation, 24(1), 61-95.

Blumberg, M., \& Pringle, C. D. (1982). The missing opportunity in organizational research: Some implications for a theory of work performance. Academy of Management Review, 7(4), 560-569.

Bosma, N., \& Levie, J. (2010). Global entrepreneurship monitor: 2009 Global Report. Retrieved 12 May 2017 from http://www.gemconsortium.org

Bosma, N., Sanders, M., \& Stam, E. (2018). Institutions, entrepreneurship, and economic growth in Europe. Small Business Economics, 51(2), 483-499.

Bowen, H. P., \& De Clercq, D. (2008). Institutional context and the allocation of entrepreneurial effort. Journal of International Business Studies, 39(4), 747-767.

Boxall, P., \& Purcell, J. (2008). Strategy and human resource management. Palgrave Macmillan. 
Bradach, J. L., \& Eccles, R. G. (1989). Price, authority, and trust: From ideal types to plural forms. Annual Review of Sociology, 15(1), 97-118.

Bruton, G. D., Ahlstrom, D., \& Obloj, K. (2008). Entrepreneurship in emerging economies: Where are we today and where should the research go in the future. Entrepreneurship: Theory \& Practice, 32(1), 1-14.

Bu, J., \& Cuervo-Cazurra, A. (2020). Informality costs: Informal entrepreneurship and innovation in emerging economies. Strategic Entrepreneurship Journal, 14(3), 329-368.

Caiazza, R. (2016). A cross-national analysis of policies affecting innovation diffusion. The Journal of Technology Transfer, 41(6), 1406-1419.

Capelleras, J. L., Mole, K. F., Greene, F. J., \& Storey, D. J. (2008). Do more heavily regulated economies have poorer performing new ventures? Evidence from Britain and Spain. Journal of International Business Studies, 39(4), 688-704.

Carpenter, R. E., \& Petersen, B. C. (2002). Capital market imperfections, high-tech investment, and new equity financing. The Economic Journal, 112(477), F54-F72.

Carter, S., Anderson, S., \& Shaw, E. (2001). Women's business ownership: A review of the academic, popular, and internet literature: Report to the small business service. Small Business Service.

Cavusgil, T., Ghauri, P., \& Agarwal, M. (2002). Doing business in emerging markets: Entry and negotiation strategies. Sage.

Chang, Y. Y., \& Gong Yand Peng, M. W. (2012). Expatriate knowledge transfer, subsidiary absorptive capacity, and subsidiary performance. Academy of Management Journal, 55(4), 927-948.

Chen, C. C., Greene, P. G., \& Crick, A. (1998). Does entrepreneurial self-efficacy distinguish entrepreneurs from managers? Journal of Business Venturing, 13(4), 295-316.

Chowdhury, F., Audretsch, D. B., \& Belitski, M. (2019). Institutions and entrepreneurship quality. Entrepreneurship Theory and Practice, 43(1), 51-81.

Clough, D. R., Fang, T. P., Vissa, B., \& Wu, A. (2019). Turning lead into gold: How do entrepreneurs mobilize resources to exploit opportunities? Academy of Management Annals, 13(1), 240-271.

Dakhli, M., \& De Clercq, D. (2004). Human capital, social capital, and innovation: A multi-country study. Entrepreneurship \& Regional Development, 16(2), 107-128.

Davidsson, P. (2015). Entrepreneurial opportunities and the entrepreneurship nexus: A re-conceptualization. Journal of Business Venturing, 30(2), 674-695.

Davidsson, P., \& Wiklund, J. (2001). Levels of analysis in entrepreneurship research: Current research practice and suggestions for the future. Entrepreneurship Theory and Practice, 25(4), 81-100.

De Clercq, D., Danis, W. M., \& Dakhli, M. (2010). The moderating effect of institutional context on the relationship between associational activity and new business activity in emerging economies. International Business Review, 19(1), 85-101.

De Clercq, D., Lim, D. S., \& Oh, C. H. (2013). Individual-level resources and new business activity: The contingent role of institutional context. Entrepreneurship Theory and Practice, 37(2), 303-330.

Drnovšek, M., Wincent, J., \& Cardon, M. S. (2010). Entrepreneurial self-efficacy and business start-up: Developing a multi-dimensional definition. International Journal of Entrepreneurial Behavior \& Research, 16(4), 329-348.

Edler, J. (2011). Innovation in EU CEE: the role of demand-based policy. In S. Radosevic \& A. Kaderábková (Eds.), Challenges for European Innovation Policy: Cohesion and Excellence from a Schumpeterian Perspective (pp. 177-208). Edward Elgar Publishing.

Estrin, S., Meyer, K. E., \& Bytchkova, M. (2006). Entrepreneurship in transition economies. In M. C. Casson (Ed.), The Oxford Handbook of Entrepreneurship (pp. 693-725). Oxford University Press.

Estrin, S., Mickiewicz, T., \& Stephan, U. (2016). Human capital in social and commercial entrepreneurship. Journal of Business Venturing, 31(4), 449-467.

Fagerberg, J., \& Srholec, M. (2008). National innovation systems, capabilities and economic development. Research Policy, 37(9), 1417-1435.

Foo, M. D., Vissa, B., \& Wu, B. (2020). Entrepreneurship in emerging economies. Strategic Entrepreneurship Journal, 14(3), 289-301.

Gaglio, C. M. (2004). The role of mental simulations and counterfactual thinking in the opportunity identification process. Entrepreneurship Theory and Practice, 28(6), 533-552.

González-López, M. J., Pérez-López, M. C., \& Rodríguez-Ariza, L. (2020). From potential to early nascent entrepreneurship: the role of entrepreneurial competencies. International Entrepreneurship and Management Journal. https://doi.org/10.1007/s11365-020-00658-x

Hayek, F. A. (1994). Competition as a discovery procedure. In I. Kirzner (Ed.), Austrian Economics: The age of Mises and Hayek (Vol. 3, pp. 273-283). Pickering and Chatto.

Henrekson, M., \& Sanandaji, T. (2020). Measuring entrepreneurship: Do established metrics capture Schumpeterian entrepreneurship? Entrepreneurship Theory and Practice, 44(4), 733-760. 
Hessels, J., Van Gelderen, M., \& Thurik, R. (2008). Entrepreneurial aspirations, motivations, and their drivers. Small Business Economics, 31(3), 323-339.

Hitt, M. A. (2016). International strategy and institutional environments. Cross Cultural and Strategic Management, 23(2), 206-215.

Hoang, H., \& Antoncic, B. (2003). Network-based research in entrepreneurship: A critical review. Journal of Business Venturing, 18(2), 165-187.

Hofmann, D. A. (1997). An overview of the logic and rationale of hierarchical linear models. Journal of Management, 23(6), 723-744.

Hofmann, D. A., \& Gavin, M. B. (1998). Centering decisions in hierarchical linear models: Implications for research in organizations. Journal of Management, 24(5), 623-641.

Hoskisson, R. E., Wright, M., Filatotchev, I., \& Peng, M. W. (2013). Emerging multinationals from midrange economies: The influence of institutions and factor markets. Journal of Management Studies, 50(7), 1295-1321.

Khanna, T., \& Palepu, K. (1999). Policy shocks, market intermediaries, and corporate strategy: The evolution of business groups in Chile and India. Journal of Economics \& Management Strategy, 8(2), 271-310.

Khoury, T. A., Cuervo-Cazurra, A., \& Dau, L. A. (2014). Institutional outsiders and insiders: The response of foreign and domestic inventors to the quality of intellectual property rights protection. Global Strategy Journal, 4(3), 200-220.

Khoury, T. A., Junkunc, M., \& Mingo, S. (2015). Navigating political hazard risks and legal system quality: Venture capital investments in Latin America. Journal of Management, 41(3), 808-840.

Kirzner, I. M. (1973). Competition and entrepreneurship. University of Chicago Press.

Kleinknecht, A. (1987). Measuring R\&D in small firms: How much are we missing? Journal of Industrial Economics, 36(2), 253-256.

Koellinger, P., Minniti, M., \& Schade, C. (2007). "I think I can, I think I can”: Overconfidence and entrepreneurial behavior. Journal of Economic Psychology, 28(4), 502-527.

Kolvereid, L. (1992). Growth aspirations among Norwegian entrepreneurs. Journal of Business Venturing, 7(3), 209-222.

Kostova, T., \& Roth, K. (2002). Adoption of an organizational practice by subsidiaries of multinational corporations: Institutional and relational effects. Academy of Management Journal, 45(1), 215-233.

Kumar, V., Mudambi, R., \& Gray, S. (2013). Internationalization, innovation and institutions: The 3 I's underpinning the competitiveness of emerging market firms. Journal of International Management, 19(3), 203-206.

Lim, D. S., Oh, C. H., \& De Clercq, D. (2016). Engagement in entrepreneurship in emerging economies: Interactive effects of individual-level factors and institutional conditions. International Business Review, 25(4), 933-945.

Livesay, H. C. (1982). Entrepreneurial history. In C. A. Kent, D. L. Sexton, \& K. H. Vesper (Eds.), Encyclopedia of entrepreneurship (pp. 7-19). Prentice-Hall.

Lounsbury, M., \& Glynn, M. A. (2001). Cultural entrepreneurship: Stories, legitimacy, and the acquisition of resources. Strategic Management Journal, 22(6-7), 545-564.

Manolova, T. S., Eunni, R. V., \& Gyoshev, B. S. (2008). Institutional environments for entrepreneurship: Evidence from emerging economies in Eastern Europe. Entrepreneurship: Theory \& Practice, 32(1), 203-218.

Marquis, C., \& Raynard, M. (2015). Institutional strategies in emerging markets. The Academy of Management Annals, 9(1), 291-335.

McMullen, J. S., \& Shepherd, D. A. (2006). Entrepreneurial action and the role of uncertainty in the theory of the entrepreneur. Academy of Management Review, 31(1), 132-152.

Mitchelmore, S., \& Rowley, J. (2010). Entrepreneurial competencies: A literature review and development agenda. International Journal of Entrepreneurial Behavior \& Research, 16(2), 92-111.

Morris, M. H., Miyasaki, N. N., Watters, C. E., \& Coombes, S. M. (2006). The dilemma of growth: Understanding venture size choices of women entrepreneurs. Journal of Small Business Management, 44(2), 221-244.

Olavarrieta, S., \& Villena, M. G. (2014). Innovation and business research in Latin America: An overview. Journal of Business Research, 67(4), 489-497.

Peterson, M. F., Arregle, J. L., \& Martin, X. (2012). Multilevel models in international business research. Journal of International Business Studies, 43(5), 451-457.

Pezeshkan, A., Smith, A., Fainshmidt, S., \& Sedeh, A. A. (2016). National business systems and firm innovation: A study of developing economies. Journal of Business Research, 69(11), 5413-5418.

Porter, M. E. (1990). The competitive advantage of nations. Competitive Intelligence Review, 1(1), 14-14. 
Prandelli, E., Pasquini, M., \& Verona, G. (2016). In user's shoes: An experimental design on the role of perspective taking in discovering entrepreneurial opportunities. Journal of Business Venturing, 31(3), 287-301.

Prieto Pastor, I. M., Perez Santana, M. P., \& Martín Sierra, C. (2010). Managing knowledge through human resource practices: Empirical examination on the Spanish automotive industry. International Journal of Human Resource Management, 21(13), 2452-2467.

Raudenbush, S. W., \& Bryk, A. S. (2002). Hierarchical linear models: Applications and data analysis methods (Vol. 1). Sage.

Reynolds, P. D., Bosma, N., Autio, E., Hunt, S., De Bono, N., Servais, I., \& Chin, N. (2005). Global entrepreneurship monitor: Data collection design and implementation 1998-2003. Small Business Economics, 24(3), 205-231.

Roper, S., \& Scott, J. M. (2009). Perceived financial barriers and the start-up decision an econometric analysis of gender differences using GEM data. International Small Business Journal, 27(2), 149-171.

Rosenberg, N. (1972). Factors affecting the diffusion of technology. Explorations in Economic History, 10(1), 3-33.

Rosenbusch, N., Brinckmann, J., \& Bausch, A. (2011). Is innovation always beneficial? A meta-analysis of the relationship between innovation and performance in SMEs. Journal of Business Venturing, 26(4), $441-457$.

Samuelsson, M., \& Davidsson, P. (2009). Does venture opportunity variation matter? Investigating systematic process differences between innovative and imitative new ventures. Small Business Economics, 33(2), 229-255.

Schumpeter, J. A. (1983). The theory of economic development. Transaction Publishers.

Shane, S. (2009). Why Encouraging More People to Become Entrepreneurs is Bad Public Policy. Small Business Economics, 33(2), 141-149.

Shane, S., Locke, E. A., \& Collins, C. J. (2003). Entrepreneurial motivation. Human Resource Management Review, 13(2), 257-279.

Shane, S., \& Venkataraman, S. (2000). The promise of entrepreneurship as a field of research. Academy of Management Review, 25(1), 217-226.

Shipton, H., Sparrow, P., Budhwar, P., \& Brown, A. (2017). HRM and innovation: Looking across levels. Human Resource Management Journal, 27(2), 246-263.

Singh, G., \& Verma, A. (2001). Is there life after career employment? Labour market experience of early retirees. In V. Marshall, W. Heinz, H. Krueger, \& A. Verma (Eds.), Restructuring work and the life course (pp. 288-302). University of Toronto Press.

Spencer, J. W., \& Gomez, C. (2004). The relationship among national institutional structures, economic factors, and domestic entrepreneurial activity: A multicountry study. Journal of Business Research, 57(10), 1098-1107.

Stenholm, P., Acs, Z. J., \& Wuebker, R. (2013). Exploring country-level institutional arrangements on the rate and type of entrepreneurial activity. Journal of Business Venturing, 28(1), 176-193.

Stephan, U., \& Uhlaner, L. M. (2010). Performance-based vs socially supportive culture: A cross-national study of descriptive norms and entrepreneurship. Journal of International Business Studies, 41(8), 1347-1364.

Stephan, U., Uhlaner, L. M., \& Stride, C. (2015). Institutions and social entrepreneurship: The role of institutional voids, institutional support, and institutional configurations. Journal of International Business Studies, 46(3), 308-331.

Schwartz, S (2006) Basic human values: An overview.

Tracey, P., \& Phillips, N. (2011). Entrepreneurship in emerging markets. Management International Review, 51(1), 23-39.

Urbano, D., \& Alvarez, C. (2014). Institutional dimensions and entrepreneurial activity: An international study. Small Business Economics, 42(4), 703-716.

Venkataraman, S. (2004). Regional transformation through technological entrepreneurship. Journal of Business Venturing, 19(1), 153-167.

Verheul, I., Wennekers, S., Audretsch, D., \& Thurik, R. (2002). An eclectic theory of entrepreneurship: Policies, institutions and culture. Entrepreneurship: Determinants and policy in a European-US comparison (pp. 11-81). Springer.

Webb, J., Khoury, T., \& Hitt, M. A. (2019). The influence of formal and informal institutional voids on productive entrepreneurship in developing economies. Entrepreneurship Theory and Practice, 44(3), 504-526.

Welter Fand Smallbone, D. (2011). Institutional perspectives on entrepreneurial behavior in challenging environments. Journal of Small Business Management, 49(1), 107-125. 
Wennekers, S., \& Thurik, R. (1999). Linking entrepreneurship and economic growth. Small Business Economics, 13(1), 27-56.

Wennekers, S., van Stel, A., Thurik, R., \& Reynolds, P. (2005). Nascent entrepreneurship and the level of economic development. Small Business Economics, 24(3), 293-309.

Witt, M. A., \& Lewin, A. Y. (2007). Outward foreign direct investment as escape response to home country institutional constraints. Journal of International Business Studies, 38(4), 579-594.

Wright, M., \& Hitt, M. A. (2017). Strategic entrepreneurship and the SEJ: Development and current progress. Strategic Entrepreneurship Journal, 11(3), 200-210.

Zhou, J., Ge, L. G., Li, J., \& Chandrashekar, S. P. (2020). Entrepreneurs' socioeconomic status and government expropriation in an emerging economy. Strategic Entrepreneurship Journal, 14(3), 396-418.

Publisher's Note Springer Nature remains neutral with regard to jurisdictional claims in published maps and institutional affiliations. 